\title{
Isolation and Characterization of Rare Earth Element-Binding Protein in Roots of Maize
}

\author{
Dong-an Yuan, Xiao-quan Shan, * Bei Wen, \\ AND QING HUAI \\ Research Center for Eco-Environmental Sciences, Chinese \\ Academy of Sciences, P.O. Box 2871, Beijing 100085, China
}

Received April 13, 2000; Accepted June 1, 2000

\begin{abstract}
Rare earth element-binding protein was isolated from maize, which was grown under greenhouse conditions and characterized in terms of molecular weight, amino acid composition, and ultraviolet absorption. The molecular weight of the maize protein was determined to be 183,000 , with two distinct subunits of approximately molecular weights of 22,000 and 69,000 , respectively. The protein is particularly rich in asparagine/aspartic acid, glutamine/glutamic acid, glycine, alanine, and leucine and contains $8.0 \%$ of covalently bound carbohydrate. The ultraviolet absorption of the protein is low at $280 \mathrm{~nm}$ and no change in the adsorption was observed with a change in $\mathrm{pH}$. Compared to the unique features of the metallothioneins with a molecular weight of approximately 10,000, a high cysteine content of $30 \%$, high absorption at $254 \mathrm{~nm}$ and a low absorption at $280 \mathrm{~nm}$, and absorption change with $\mathrm{pH}$, the REE-binding protein is unlikely to be plant metallothionein in nature. It was found that an almost twofold greater concentration was found for most of the REEs in the protein isolated from the maize with REE fertilizer use than that without REE fertilizer. This study suggests that the REE-binding protein is a glycoprotein and REEs can be firmly bound with the protein of maize roots.
\end{abstract}

Index Entries: Rare earth elements; maize; isolation and characterization of protein.

*Author to whom all correspondence and reprint requests should be addressed. 


\section{INTRODUCTION}

The rare earth elements (REEs) are members of Group IIIA in the periodic table and have similar physical and chemical properties (1). In recent years, more and more REEs enter the environment and food chain through various pathways because of the rapid increase of the exploitation of REEs resources and its applications to modern industry and daily life (2). Moreover, millions of tons of fertilizers containing REEs are used worldwide for increasing agricultural productivity (3). In China, REE fertilizers for agriculture use was predicted to cover over $(16-20) \times 10^{6}$ hectares in 1995 (4) and many typical farm plants, such as corn, fruit, tea, and vegetables are fertilized nowadays (5). Although REEs have been found in plants for more than $100 \mathrm{yr}(6)$, until now the physiological and biochemical effects of REEs on plants are still uncertain. Several ill effects resulting from the occupational and environmental exposure to REEs have also been reported (7-9), but there are no consistent evaluations available for the long-term biological effects on plants, animals, and human health in literature.

Over the past three decades, the research related to heavy metal toxicology has been focused on cadmium, mercury, lead, chromium, nickel, vanadium, and tin because these metals seriously pollute the environment (10). In the meantime, heavy-metal-binding complexes, especially metallothioneins, found in the cytoplasm of plant cells are widely reported to be responsible for metal resistance (11-14). It is generally recognized that these metallothioneins play an important role in the accumulation of heavy metals and in the detoxicification as well. As far as the adsorption and/or uptake mechanism of REEs by plants is concerned, there were several reports in the literature. Lanthanum deposits were found only in cell walls and on the outside of the plasma membrane of epidermal, cortical, and endodermal cells of maize roots (15) and europium was bound to the roots of water hyacinth via carboxylate groups and hydration of $\mathrm{Eu}(\mathrm{III})$ at the root surface (16). Timeresolved laser-induced fluorescence spectroscopy on europium-loaded Pseudomonas aeruginosa suggested that europium binding occurred mostly through carboxyl and phosphate groups (17). It should be pointed out that trace elements are mainly incorporated with proteins in biological matter (18). In order to elucidate the biochemical functions and possible long-term hazardous effects of REEs on the environment, the first step to be taken is to isolate and to characterize the REE-binding proteins in plants. Considering that maize as a widely planted agronomic crop in the world, higher accumulation of REEs in maize roots and cadmiumbinding metallothionein are isolated from maize roots (19). The aim of the present article is to isolate and characterize the REE-binding protein from maize roots. 


\section{MATERIALS AND METHODS}

\section{Chemicals and Reagents}

All reagents used were of analytical grade or better. For highperformance liquid chromatography (HPLC) use, all solvents were of HPLC grade and filtered with a $0.45-\mu \mathrm{m}$ membrane prior to use.

\section{Maize}

Seeds of maize (Zea mays L.) were obtained from the Chinese Academy of Agriculture, Beijing and soaked in aerated deionized water for $6 \mathrm{~h}$ on moist filter paper in Petri dishes and placed in the dark at $20^{\circ} \mathrm{C}$ for germination. The germinated seedlings were then transplanted into the individual jars containing a full culture solution (20) and grown for $6 \mathrm{wk}$ with weekly changes of the same culture solution. At the 14th and 28th d after planting, the seedlings were separately sprayed with REE fertilizer containing $\mathrm{Y}(15.1 \mu \mathrm{g} / \mathrm{mL}), \mathrm{La}\left(6.9 \times 10^{3} \mu \mathrm{g} / \mathrm{mL}\right)$, Ce $\left(1.37 \times 10^{4} \mu \mathrm{g} / \mathrm{mL}\right)$, $\operatorname{Pr}\left(1.5 \times 10^{3} \mu \mathrm{g} / \mathrm{mL}\right), \mathrm{Nd}\left(4.8 \times 10^{3} \mu \mathrm{g} / \mathrm{mL}\right), \mathrm{Sm}(14.7 \mu \mathrm{g} / \mathrm{mL}), \mathrm{Gd}$ $(297 \mu \mathrm{g} / \mathrm{mL}), \mathrm{Tb}(15.7 \mu \mathrm{g} / \mathrm{mL})$, Dy $(59.4 \mu \mathrm{g} / \mathrm{mL})$, and $\operatorname{Er}(24.4 \mu \mathrm{g} / \mathrm{mL})$.

After maize was harvested, the roots were rinsed carefully first with a large volume of cold tap water and then with deionized water, and then blotted with paper towels. The roots were either used at once or frozen in liquid nitrogen for later use.

\section{Protein Isolation and Purification}

Fifty grams of the fresh roots were homogenized with $150 \mathrm{~mL}$ of $0.02 M$ Tris- $\mathrm{HCl}(\mathrm{pH} 8.0), 5 \mathrm{mM}$ ascorbic acid, $50 \mathrm{mM}$ sucrose, $1 \mathrm{mM}$ phony methyl sulfonyl fluoride (PMSF), $5 \mathrm{mM} \mathrm{NaCl}$, and $5 \mathrm{mM} 2-$ mercaptoethanol in a mortar and pestle. The homogenate was strained through cheesecloth and centrifuged at $20,000 \mathrm{~g}$ for $30 \mathrm{~min}$. The final supernatant was collected in a $200-\mathrm{mL}$ and $70 \mathrm{~g}$ of ammonium sulfate was added, the mixture was stirred for $10 \mathrm{~min}$ to precipitate protein, then the mixture was quantitatively distributed to four centrifuge tubes $(50 \mathrm{~mL})$ and centrifuged at 20,000 $\mathrm{g}$ for $20 \mathrm{~min}$, and the supernatant was decanted and the obtained precipitate was combined. Finally, the obtained precipitate was dissolved with $20 \mathrm{~mL}$ of $0.02 \mathrm{M}$ Tris- $\mathrm{HCl}$. The solution was fractionated via gel filtration using a Sephadex G-100 column $(70 \times 2.6 \mathrm{~cm})$ (Pharmacia Fine Chemicals) equilibrated with $0.02 \mathrm{M}$ Tris- $\mathrm{HCl}(\mathrm{pH} 8.0)$ and the sample was eluted at a flow rate of $1 \mathrm{~mL} / \mathrm{min}$ with the same buffer. The appropriate fractions were collected and desalted with Sephadex G-25 column using deionized water as an eluant. Then, the sample was concentrated by ultrafiltration with a Diaflo UM2 membrane (Amicon Corporation) and lyophilized. All the operations 
of the isolation of proteins were carried out at $4^{\circ} \mathrm{C}$ in an enclosure purged with nitrogen gas.

\section{Characterization of Protein}

The obtained protein was determined by the method of Bradford (21) using bovine serum albumin as a standard. The protein was analyzed and its molecular weights were determined with a HP 1100 HPLC system (Hewlett-Packard, Wilmington, DE, USA) equipped with a TSK $3000 S W(30 \times 0.75 \mathrm{~cm})$ gel permeation column and TSK 3000SW precolumn $(7.5 \times 0.75 \mathrm{~cm})$. The columns were equilibrated with $0.1 \mathrm{M}$ $\mathrm{Na}_{2} \mathrm{HPO}_{4}-\mathrm{NaH}_{2} \mathrm{PO}_{4}$ buffer $(\mathrm{pH}$ 7.0) and eluted at a flow rate of $1 \mathrm{~mL} / \mathrm{min}$. The proteins used for the molecular-weight calibration of the maize protein and their molecular weights were as follows: myosin $(205,000)$, $\beta$-galactosidase $(116,000)$, bovine serum albumin $(66,000)$, egg albumin $(45,000)$, and pepsin $(34,700)$, lysozyme $(14,300)$. The protein was also subjected to sodium dodecyl sulfate/polyacrylamide gel electrophoresis (SDS-PAGE) on 12.5-25\% (w/v) amide gradient gels and dyed with Coomassie brilliant blue G-250 (22). The obtained protein was hydrolyzed in $\mathrm{N}_{2}$-saturated $6 \mathrm{M} \mathrm{HCl}$ at $110^{\circ} \mathrm{C}$ for $24 \mathrm{~h}$. Amino acid analysis was accomplished with a Beckman $121 \mathrm{MB}$ amino acid analyzer. The total neutral sugar was determined by the phenol $/ \mathrm{H}_{2} \mathrm{SO}_{4}$ method with D-glucose as a standard (23). The ultraviolet absorption was measured with a UV 3000 (Shimadzu, Kyoto, Japan).

\section{Determination of REEs}

A Plasma Quad 3 (VG Elemental, Winsford, UK) inductively coupled plasma-mass spectrometer (ICP-MS) was used for the determination of REEs under the optimum operating conditions. A portion of $2 \mathrm{~mL}$ of the protein solution fractionated via gel filtration was accurately taken into a Teflon vessel and decomposed with $\mathrm{HNO}_{3} / \mathrm{HClO}_{4}(3: 1 \mathrm{v} / \mathrm{v})$ to near dryness; then the residue was dissolved with $1 \% \mathrm{HNO}_{3}$ and quantified to $3 \mathrm{~mL}$ for the determination of REEs. During the determination, a solution of $10 \mathrm{ng} / \mathrm{mL}{ }^{115} \mathrm{In}$ in $2 \% \mathrm{HNO}_{3}$ was also used as an internal standard to compensate for the matrix suppression and signal drift.

\section{RESULTS AND DISCUSSION}

In order to study whether REEs are bound with the maize protein, the protein obtained at the step with ammonium sulfate precipitation was dissolved with $0.02 \mathrm{M}$ Tris- $\mathrm{HCl}$ and subjected to a preparative gel column of Sephadex G-100. The elution fractions were collected and the REEs in each fraction were determined. The results are shown in Fig. 1. 
A

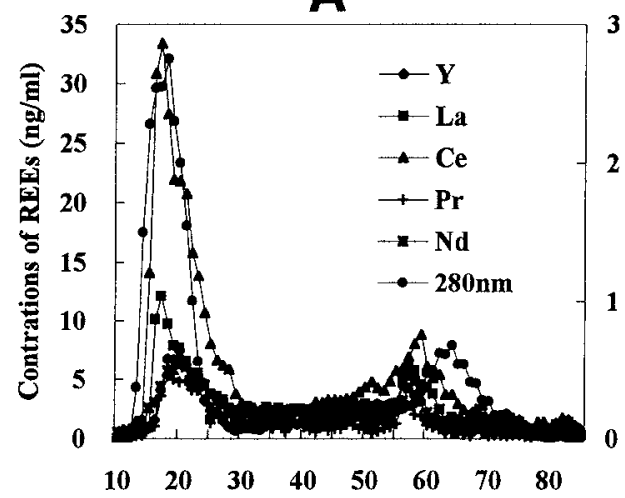

C

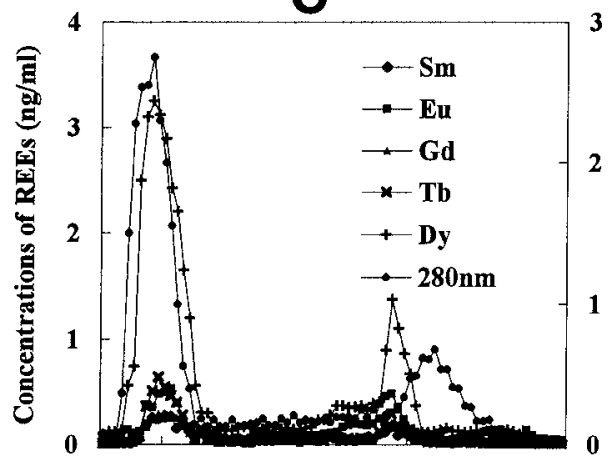

$\begin{array}{llllllll}10 & 20 & 30 & 40 & 50 & 60 & 70 & 80\end{array}$

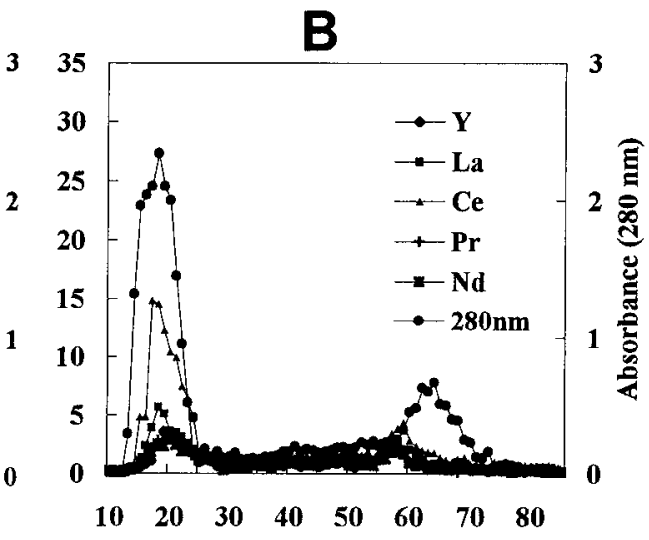

E
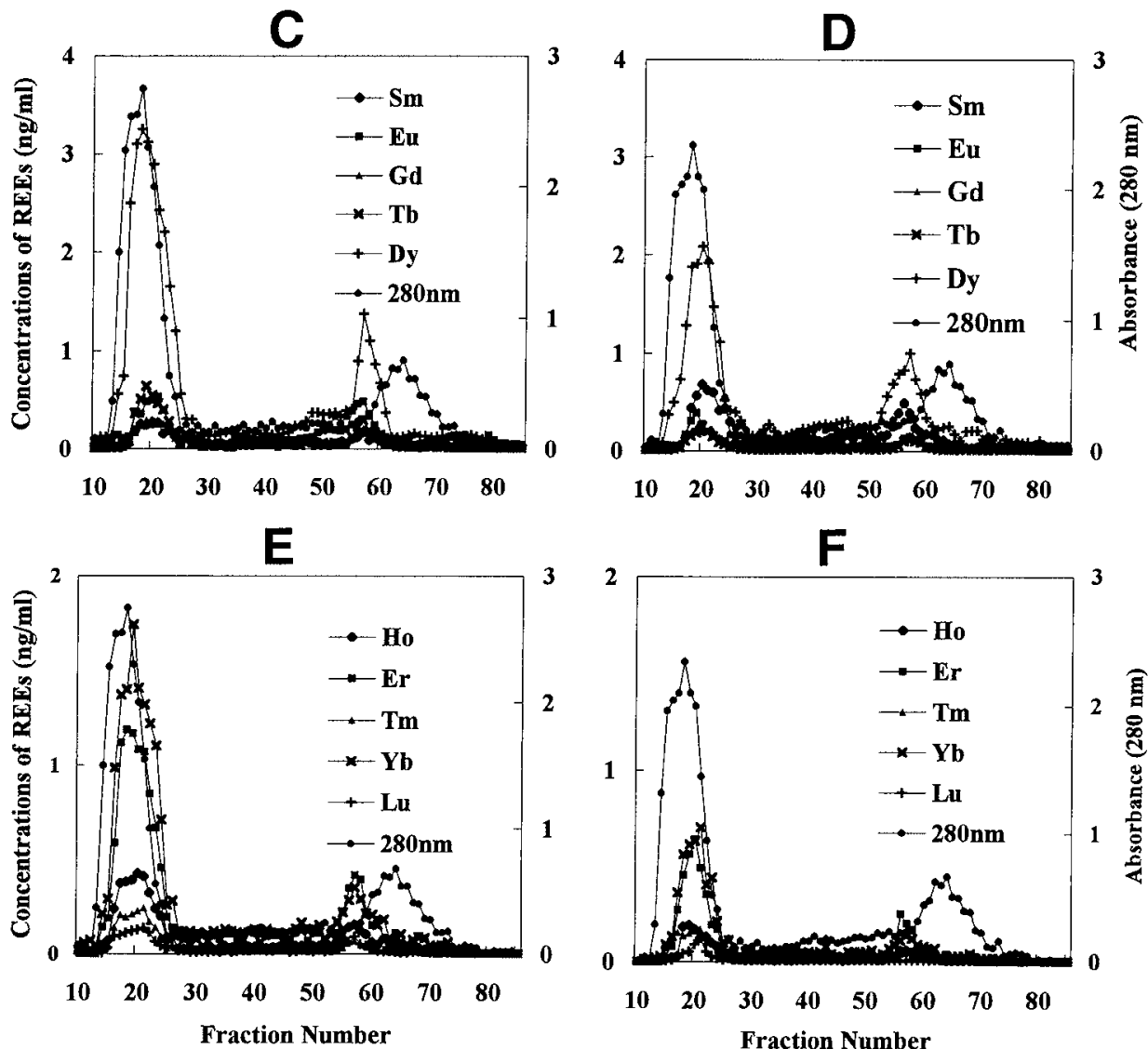

$\mathbf{F}$

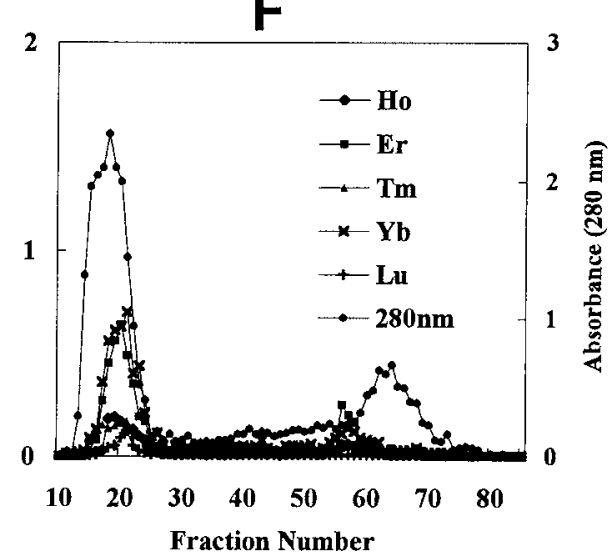

Fig. 1. Elution profiles of proteins with a Sephadex G-100 column and the average concentration of REEs in proteins $(n=5)$ : $(\mathrm{A}, \mathrm{C}, \mathrm{E})$ treated with REEfertilizer $(\mathbf{B}, \mathbf{D}, \mathbf{F})$ untreated. 
It can be seen clearly that there are two components for maize protein regardless of whether REE fertilizer was applied. Components 1 and 2 consist of the fractions 13-22 and fractions 58-70, respectively. It was verified that up to $50-70 \%$ of the total REEs in the protein were associated mainly with component 1 , which has a high molecular weight, and all the individual REEs exert quite similar behaviors in this regard. In contrast, there are much less REEs in component 2. It should be pointed out that the concentrations of the individual REEs in protein components 1 and 2 followed the order $\mathrm{Ce}>\mathrm{La}>\mathrm{Nd}>\mathrm{Y}>\mathrm{Pr}>\mathrm{Sm}>\mathrm{Gd}>\mathrm{Dy}>\mathrm{Er}$ $>\mathrm{Yb}>\mathrm{Eu}>\mathrm{Tb}>\mathrm{Ho}>\mathrm{Tm}>\mathrm{Lu}$. This is consistent with the concentration order of REEs in the maize. As far as the differences between the proteins and the concentrations of REEs in the proteins are concerned, the absorption of the protein isolated from maize grown in the soil with REE fertilizer (Fig. 1a,c,e) was slightly higher than that without REE fertilizer (Fig. 1b,d,f); this means that the REE-fertilizer application did not exert a significant effect on the content of the maize proteins (i.e., the REE fertilizer cannot induce a specific protein). Nevertheless, it should be pointed out that the concentrations of REEs in Fig. 1a,c,e were generally twofold that in Fig. 1b,d,f for $\mathrm{Y}, \mathrm{La}, \mathrm{Ce}, \mathrm{Pr}, \mathrm{Nd}, \mathrm{Tb}, \mathrm{Dy}, \mathrm{Ho}, \mathrm{Er}$, and $\mathrm{Yb}$, and there is not much difference between the concentrations of other REEs. From this observation, one can draw the conclusion that REEs can be firmly bound with the proteins in the maize roots.

The protein component 1 was further subjected to a TSK 3000SW gel permeation HPLC column, and the chromatogram is shown in Fig. 2. Obviously, the REE-binding protein has a single peak and the retention time is $6.218 \mathrm{~min}$. At the same time, the molecular weight of the protein was determined to be 183,000 using various molecular-weight markers (not shown). In order to study the REE-binding protein further, SDSPAGE procedure was performed and the electrophoretogram is shown in Fig. 3. The protein yielded two bands of molecular weights of 22,000 and 69,000 , respectively. This finding indicated that the protein might build up two different types of subunit held together by disulfide bonds. Based on the determination of sugar in the REE-binding protein, it was verified that the REE-binding protein is a glycoprotein, which contains $8.0 \%$ of covalently bound carbohydrate.

The amino acid composition of the protein is given in Table 1 and the results suggest that the protein is especially rich in asparagine/aspartic acid $(11.20 \mathrm{~mol} / 100 \mathrm{~mol})$, glutamine/glutamic acid $(10.95 \mathrm{~mol} / 100 \mathrm{~mol})$, alanine $(10.82 \mathrm{~mol} / 100 \mathrm{~mol})$, leucine $(9.82 \mathrm{~mol} / 100 \mathrm{~mol})$, and glycine $(9.05 \mathrm{~mol} / 100 \mathrm{~mol})$, but contains little histidine $(1.81 \mathrm{~mol} / 100 \mathrm{~mol})$, tyrosine $(2.19 \mathrm{~mol} / 100 \mathrm{~mol})$, cysteine $(1.78 \mathrm{~mol} / 100 \mathrm{~mol})$, and methionine $(1.99 \mathrm{~mol} / 100 \mathrm{~mol})$. This finding is consistent with the previous reports in the literature (23-25). These reports indicated that in the thylakoid membranes of plant chloroplasts' trivalent lanthanide cations adsorb to the surface-exposed carboxyl groups of glutamic acid and aspartic acid residues of protein complexes imbedded within the thylakoid membrane. 


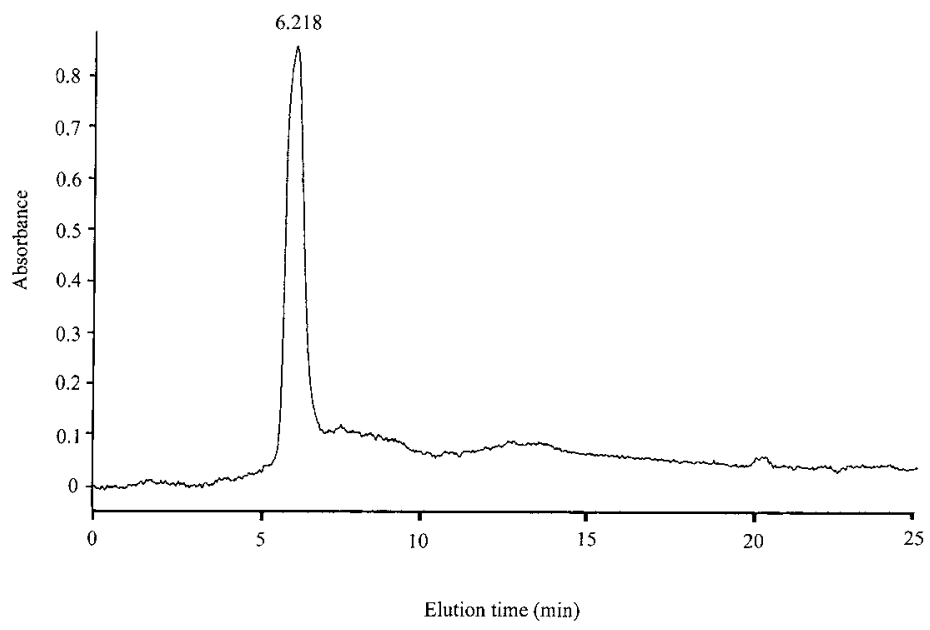

Fig. 2. Chromatogram of gel permeation HPLC of REE-binding protein on an TSK 83000SW column.

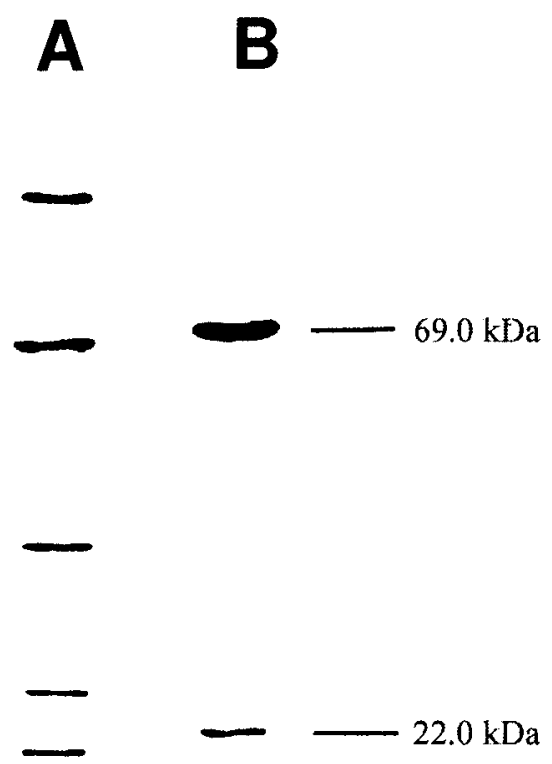

Fig. 3. Electrophoretogram of protein: (A) molecular weight of markers: phosphorylase b, 97,400; bovine serum albumin, 66,200; egg albumin, 45,000; pepsin, 34,700; lysozyme, 14,300; (B) REE-binding protein.

From the amino acid composition listed in Table 1, it is clear that the REE-binding protein has a low cysteine content.

The ultraviolet absorption spectrum of this protein is shown in Fig. 4. Due to lack of aromatic amino acids the protein has a low ultraviolet absorption at $280 \mathrm{~nm}$. In addition, the absorption has no significant change 
Table 1

Amino Acid Composition of REE-Binding Proteins from Maize Roots

\begin{tabular}{cc}
\hline Amino acid & $\begin{array}{c}\text { Amino acid } \\
\text { composition } \\
\text { (mol/100mol) }\end{array}$ \\
\hline Asp & 11.20 \\
Thr & 6.08 \\
Ser & 5.90 \\
Glu & 10.95 \\
Pro & 5.20 \\
Gly & 9.05 \\
Ala & 10.82 \\
Cys & 1.78 \\
Val & 6.16 \\
Met & 1.99 \\
Ile & 3.95 \\
Leu & 9.82 \\
Tyr & 2.19 \\
Phe & 4.15 \\
Lys & 4.74 \\
His & 1.81 \\
Arg & 4.21 \\
\hline
\end{tabular}

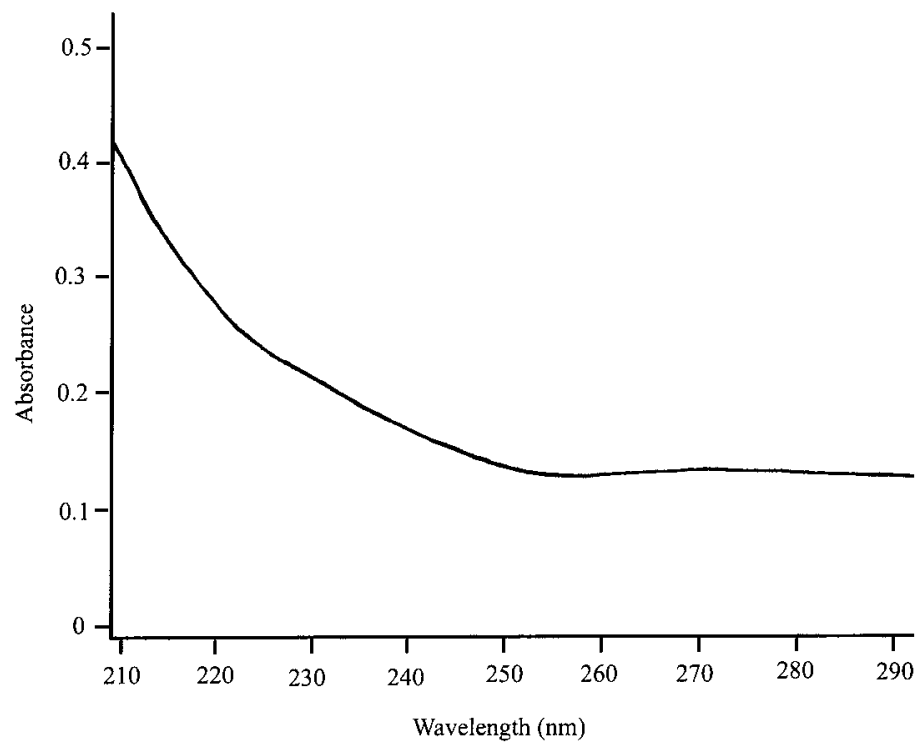


after titration to $\mathrm{pH} 2$ (not shown). However, the metallothioneins have a high absorption at $254 \mathrm{~nm}$ and a low absorption at $280 \mathrm{~nm}$. Another distinctive feature of the metallothioneins is that the absorption at $254 \mathrm{~nm}$ was significantly reduced upon acidification to $\mathrm{pH} 2$ and returned upon titration to $\mathrm{pH} 8$ (11). It is generally recognized that the decrease in absorption upon acidification is due to the breaking down of the Cd-mercaptide bonds (26). According to these unique characteristics of the molecular weight of approximately 10,000, high contents of half-cysteine residues (approx 30\%), and high absorption at $254 \mathrm{~nm}$ and low absorption at $280 \mathrm{~nm}$, it is proved that the protein obtained from the maize roots treated with REE fertilizer is different from plant metallothioneins $(19,20)$.

\section{ACKNOWLEDGMENTS}

This work was supported by the National Natural Science Foundation of China, the Chinese Academy of Sciences, and the Research Center for Eco-Environmental Sciences.

\section{REFERENCES}

1. P. Henderson, General geochemical properties and abundance of the rare earth elements, in Rare Earth Element Geochemistry, P. Henderson, ed., Elsevier, Amsterdam (1984).

2. A. A. Volokh, A. V. Gorbunov, S. F. Gundorina, and B. A. Revich, Phosphorus fertilizer production as a sourch of rare earth elements pollution of the environment, Sci. Total Environ. 95, 141-148 (1990).

3. W. Bremmer, Rare earth application in Chinese agriculture, Elements Rare Earth Spec. Metals Appl. Technol. 5, 20-24 (1994).

4. Q. Tu, X. R. Wang, L. Q. Tian, and L. M. Dai, Bioaccumulation of the rare earth elements lanthanum, gadolinium and yttrium in carp (Cyprinus carpio), Environ. Pollut. 3, 345-350 (1994).

5. B. S. Guo, Rare Earths in Agriculture, China Agricultural Science and Technology Press, Beijing (1988) (in Chinese).

6. C. H. Evans, Biochemistry of Lanthanides, Plenum, New York (1990).

7. E. Sabbioni, R. Pietra, P. Gaglione, G. Vocaturo, F. Colombo, M. Zanoni, et al., Longterm occupational risk of rare earth pneumoconiosis, Sci. Total Environ. 26, 19-32 (1982).

8. N. I. Sax, Dangerous Properties of Industrial Materials, Van Nostrand Reinhold, New York (1984).

9. G. S. Ding and H. C. Ma, Effects of rare earths on organisms, J. Environ. Sci. 5, 70-75 (1984) (in Chinese).

10. S. Hirano and K. Suzuki, Exposure, metabolism, and toxicity of rare earths and related compounds, Environ. Health Perspect. 104(Suppl. 1), 85-95 (1996).

11. M. Bartolf, E. Brennan, and C. A. Price, Partial characterization of a cadmium-binding protein from the roots of cadmium-treated tomato, Plant Physiol. 66, 438-441 (1980).

12. A. Tukencorf and T. Baszynske, Partial purification and characterization of copperbinding protein from rots of Avena sative grown excess copper, J. Plant Physiol. 120, 57-63 (1985).

13. N. H. Robinson and P. J. Jackson, "Metallothioneinlike" metal complexes in angiosperms; their structure and function, Physiol. Plant 67, 499-506 (1986).

14. M. Kaneta, H. Hikichi, S. Endo and N. Sugiyama, Chemical form of cadmium (and other heavey metals) in rice and wheat plants, Environ. Health Perspect. 65, 33-37 (1986). 
15. G. Nagahashi, W. W. Thomson, and R. T. Leonard, The Casparian strip as a barrier to the movement of lanthanum in corn roots, Science 183, 670-671 (1974).

16. C. Kelley, R. E. Mielke, D. Dimaquibo, A. J. Curtis, and J. G. Dewitt, Adsorption of $\mathrm{Eu}(\mathrm{III})$ onto roots of water hyacinth, Environ. Sci. Technol. 33, 1439-1443 (1999).

17. A. C. Texier, Y. Andres, M. Illemassene, and P. L. Cloirec, Characterization of lanthanide ions binding sites in the cell wall of Pseudomonas aeruginosa, Environ. Sci. Technol. 34, 610-615 (2000).

18. C. K. Jayawickreme and A. Chatt, Characterization of protein-bound metal species by bioanalytical and neutron activation techniques, J. Radioanal. Nucl. Chem. 124, 257-279 (1988).

19. W. E. Rauser and G. John, Cadmium-binding protein in root of maize, Can. J. Bot. 62, 1645-1650 (1984).

20. R. S. Russell and J. Sanderson, Nutrient uptake by different parts of the intact roots of plants, J. Exp. Bot. 18, 491-508 (1967).

21. M. M. Bradford, A rapid and sensitive method for the quantitation of microgram quantities of protein utilizing the principle of protein-dye binding, Anal. Biochem. 72, 248-254 (1976).

22. U. K. Laemruli, Cleavage of structural proteins during the assembly of the head of bacteriophage T4, Nature 227, 680-685 (1970).

23. M. Dubois, K. A. Gilles, P. A. Hamilton, P. A. Rebers, and F. Smith, Colorimetric method for determination of sugars and related substances, Anal. Chem. 28, 350-356 (1956).

24. H. Y. Nakatani, J. Barber, and J. A. Forrester, Surface charges on chloroplast membranes as studied by particle electrophoresis, Biochim. Biophys. Acta 504, 215-225 (1978).

25. H. Y. Nakatani and J. Barber, Further studies of the thylakoid membrane surface charges by particle electrophoresis, Biochim. Biophys. Acta 591, 82-91 (1980).

26. P. Pulido, J. H. R. Kagi, and B. L. Vallee, Isolation and some properties of human metallothionein, Biochemistry 5, 1768-1777 (1966). 